\title{
多蒸发器低温回路热管的启动特性
}

\author{
鲁得浦 ${ }^{1,2}$, 谢荣建 ${ }^{2 *}$, 文佳佳 ${ }^{2}$, 刘成 ${ }^{2,3}$ \\ 1. 中国科学院大学, 北京 100049 ; \\ 2. 中国科学院上海技术物理研究所, 上海 200083 ; \\ 3. 上海科技大学信息科学与技术学院, 上海 201210 \\ *联系人, E-mail: xierongjian@mail.sitp.ac.cn
}

2019-09-26 收稿, 2019-12-31 修回, 2020-01-02 接受, 2020-01-03 网络版发表 国家自然科学基金(51776121)资助

\begin{abstract}
摘要 空间探测技术迅速发展, 传统的点对点传热方式不再满足多阵列、大面阵结构探测器的散热需求. 本研究 通过将3个蒸发器以气耦合的方式并联，设计加工了一种用于多点热源散热的多蒸发器低温回路热管(multi-evaporator loop heat pipe, MeLHP), 并进行了样机的启动特性实验研究. 实验分别通过与单蒸发器回路热管的比较、 不同加热方式的比较以及不同充液率的比较, 多方面地探究了MeLHP在降温、启动过程中的特性. 实验发现, 在保 证样机在 $170 \mathrm{~K}$ 稳定运行的前提下, MeLHP各个支路均与单蒸发器回路热管的启动特性保持高一致性; MeLHP在 单蒸发器加热和多蒸发器共同加热的条件下均能启动, 单蒸发器加热过程中未加负载的蒸发器在气耦合作用下分 享热量保持各蒸发器温度一致, 保证三蒸发器的同时启动; 工质的初始分配状态会造成降温过程中各蒸发器温度 的差异, 气耦合的热交换作用调节了各回路温度的一致性, 有效抑制了初始状态对温度的影响; 考虑了不同充液率 的影响, 考察了充液率分别为 0.6 和 0.7 条件下的启动特性, 发现 0.7 充液率下MeLHP的启动特性能更好地与 0.6 充液 率条件下的单蒸发器回路热管相一致. 实验验证了气耦合并联形式下设计的多蒸发器回路热管的启动可行性以及 降温规律, 对MeLHP的推广应用有重要意义。
\end{abstract}

关键词多点分布热源, 多蒸发器回路热管, 降温过程, 启动特性, 充液率

随着空间探测技术的发展，航天探测器的探测阵 列为了满足宽视场的需求, 探测器元件的发展呈现结 构愈发复杂、热源分散分布的特点, 空间热控设计亟 待解决多个分散热源的高效散热问题. 热管作为空间 载荷热控领域发展成熟的高效两相传热部件，已经广 泛应用于空间载荷散热任务中. 回路热管(loop heat pipe, LHP)作为传统槽道热管的改进, 将气体管路与液 体管路完全分离, 使得蒸发器和冷凝器结构灵活多变, 有着传输管路具有柔性, 受重力影响较小的特点, 引起 国内外空间探测领域的关注. 国内对回路热管的研究 已经涉及运行机理、模型建立和结构研究各个方
面 $^{[1 \sim 3]}$. 在此基础上, 多蒸发器回路热管(multi-evaporator loop heat pipe, MeLHP)作为一种异型回路热管, 对 传统的回路热管提出了结构上的改进，其采用增加蒸 发器个数的方式形成多管路网状结构的回路热管, 在 有效将多个点热源的热量进行收集和排散的同时，可 以有效减少热控系统的质量, 提高系统集成化程度, 在 未来航天热控系统传热设备的研究中颇具前景, 已成 为回路热管近来研究的热点 ${ }^{[4]}$.

最早的多蒸发器回路热管概念由Maydanik提出 ${ }^{[5]}$. Maydanik于1988年研制成功第一台采用钛吸液芯，以 丙酮为工质的双蒸发器回路热管. 他指出, 通过蒸发器

引用格式: 鲁得浦, 谢荣建, 文佳佳, 等. 多蒸发器低温回路热管的启动特性. 科学通报, 2020, 65: 1141-1150 Lu D P, Xie R J, Wen J J, et al. Startup characteristics of a multi-evaporator cryogenic loop heat pipe (in Chinese). Chin Sci Bull, 2020, 65: 1141-1150, doi: 10.1360/TB-2019-0568 
并行、分散排布可解决大接触面积热源及分散点热源 的散热问题. 随后，Bienert等人 ${ }^{[6]}$ 和Yun等人 ${ }^{[7]}$ 分别以 水、丙酮为工质，设计了双蒸发器回路热管并进行了 实验验证. $\mathrm{Ku}$ 等人 ${ }^{[8]}$ 以及 $\mathrm{Nagano}$ 和 $\mathrm{Ku}^{[9]}$ 设计了双蒸发 器双冷凝器的回路热管并进行了大量实验, 双蒸发器 回路热管结构及其相应计算模型的研究随后得到了充 分发展. Yun等人 ${ }^{[10]}$ 在毛细葲回路的结构基础上设计 了双蒸发器的毛细泵回路(capillary pumped loop, $\mathrm{CPL}$ ), 将多蒸发器结构运用到CPL上, 避免了补偿器 蒸发器之间毛细连接的限制. Bugby等人 ${ }^{[11,12]}$ 为ST8项 目中小卫星热控系统设计了混合式的小型多蒸发器氨 回路热管, 通过在冷凝器一侧设计次蒸发器与补偿器 相连，实现了MeLHP与MeCPL优点的结合，分别设计 了单蒸发器、双蒸发器、四蒸发器的样机进行试验. 与此同时, 国内也开展了相关研究. 陈健等人 ${ }^{[13]}$ 以氨为 工质设计了多蒸发器毛细泵回路热管装置, 实现 8 个蒸 发器回路并联的换热装置. 刘成志等人 ${ }^{[14]}$ 以乙烷为工 质设计了双蒸发器低温回路热管，完成了多蒸发器回 路热管在低温区的应用. 可以发现, 多蒸发器回路热管 应用越来越广泛, 具有相当的研究前景和价值. 对低温 回路热管而言，回路热管的降温、启动规律关乎实际 应用中启动控制、稳定维持启动状态的要求，因而很 多学者对其启动特性展开研究 ${ }^{[15]}$, 但是鲜有专门针对 MeLHP的启动特性研究. 本研究通过以较为成熟的单 蒸发器回路热管作为参考, 对影响热管启动的参数进 行对比研究, 实现对MeLHP的启动特性进行详细地描 述和分析.

\section{1 原理与结构设计}

回路热管是利用气液两相相变进行热量高效传输 的部件, 工质从回路热管热端(蒸发器)吸热蒸发, 经气
体管路流至回路热管冷端(冷凝器)进行冷凝. 多蒸发器 回路热管是通过增加蒸发器个数实现向同一个冷凝器 进行循环相变换热的传热部件.

常用的多蒸发器回路热管实现方式有热耦合和气 耦合两种方式. 热耦合下的MeLHP各蒸发器回路独立 流动，各回路同单回路热管一样保证单独的启动运行, 在冷端通过相互的热传导实现热量交换. 由于热传导 过程存在热阻较大, 换热效率低的缺点; 气耦合则是指 多个蒸发器共用冷凝器的同时，气液管线并联汇人同 一回路，因而各回路之间存在工质交换，换热效率较 高, 此时各回路的热力状态会互相影响, 其启动运行过 程更加复杂. 由于单一冷凝器提供冷源的情形下, 各个 点热源加热负载往往不同，在换热效率较低的热耦合 方式下, 热端的平衡温度各不相同, 各蒸发器很难达到 同一温度区间而同时满足控温需求。气耦合方式由于 各支路间有工质的交换，各个蒸发器之间往往存在热 分享而有一定的均温特性. 实际应用考量下本研究选 用气耦合方式进行MeLHP的设计。气耦合形式下的 MeLHP按补偿器不同布置连接方式分为 3 种形式, 如图 1所示.

（1）每个蒸发器对应各自的补偿器，但每个补偿器 不与其他蒸发器直接连接. 该形式的多蒸发器回路热 管各回路补偿器和蒸发器互不约束，二者通过管线相 连接, 管路设计最为灵活, 但补偿器冷凝液回流过程受 到很大程度的影响。

（2）每个蒸发器回路有各自补偿器, 每个补偿器直 接与其他蒸发器的补偿器相连. 该形式下的多蒸发器 回路热管特点为：各回路为典型的单蒸发器回路热管 结构, 适用于各蒸发器规整排列的形式, 能最大程度保 证补偿器对吸液芯的供液.

(3) 所有蒸发器共用一个共同的补偿器, 补偿器单
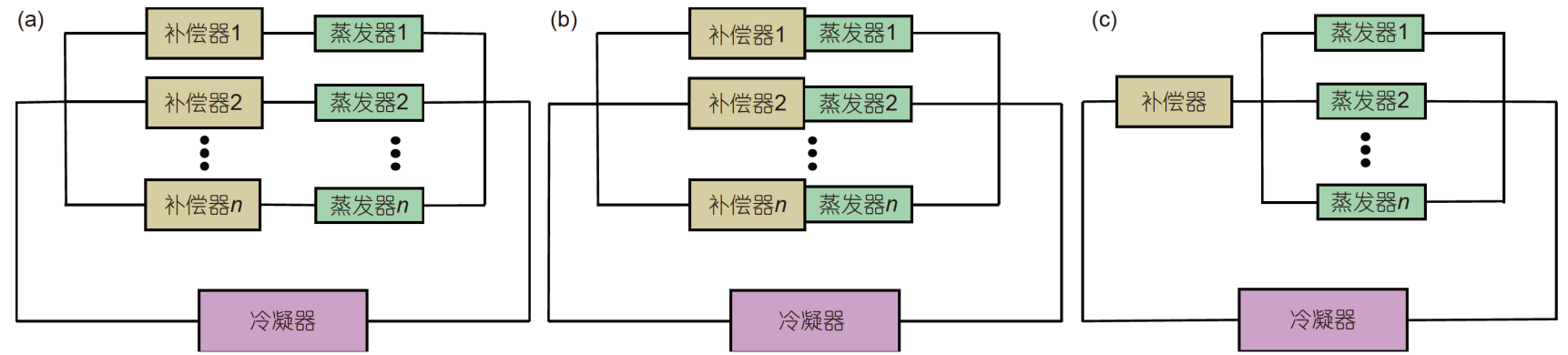

图 1 (网络版彩色)不同结构的多蒸发器回路热管. (a) 独立补偿器不直接相连; (b) 独立补偿器直接相连; (c) 共用同一补偿器

Figure 1 (Color online) Multi-evaporator loop heat pipes with different structures. (a) Independent compensation chambers separately connected; (b) independent compensation chambers directly connected; (c) common compensation chamber 
独布置控制各回路蒸发器的工作状态. 该形式的多蒸 发器回路热管类似于毛细泵流体回路CPL，便于对整 个回路状态的统一调控.

为保证多蒸发器回路热管具有高可靠性和实用性, 同时便于启动运行规律的研究, 采用了各蒸发器具有 独立补偿器直接相连的方案, 其结构示意如图2(a)所 示. 采用蒸发器补偿器一体化设计, 3 个蒸发器通过气 液管线的并联接人共同回路中, 实现同一个冷凝器的 共用. 工质在 3 个蒸发器受热蒸发为过热蒸气, 经气体 管线汇流后进人冷凝器冷凝, 过冷液体流出后沿液体 管线分流至各个补偿器, 进人下一个循环.

气耦合型独立补偿器直连的多蒸发器回路热管热 力过程的 $P-T$ 图如图2(b)所示, 3 个回路均正常稳定工作 时, 回路工质维持稳定的循环状态, 图中各点状态在实 际MeLHP中的结构对应图2(a)所标示的点. 相较于单蒸 发器LHP, 由于加热负载的差异、毛细芯加工的随机性 以及管路的不均匀布置, MeLHP中每个蒸发器对应的 曲线有所区别. 不同工况下的蒸发器内工质于饱和曲 线不同位置发生相变(1、1'、1"), 产生的过热蒸气在 气体槽道内进一步受蒸发器管壳加热直至气体人口处 (2、2、 $\left.2^{\prime \prime}\right)$, 各管线蒸气过热度增加, 压力减小, 在总管 线3点处交汇于同一热力状态, 而后沿气体管线(3 4)流 动, 压力继续降低, 而由于低温热管运行时环境漏热对 气体管线有加热作用，沿气体管线工质温度持续升高. 随后过热蒸气在冷凝器中冷凝(4 7), 分别经历过热蒸
气降温过程的过热段 $(4 \sim 5)$ 、饱和蒸汽冷凝过程的两相 段(5 6), 以及冷凝液继续降温的过冷段 $(6 \sim 7)$. 过冷液 经液体管线(7 8)流动受流阻影响压力减少, 受漏热影 响温度升高, 在分流点 8 处冷凝液分流至不同管路. 由 于管路结构、热端状态的影响, 最终进人各补偿器人 口 $\left(9 、 9^{\prime} 、 9^{\prime \prime}\right)$ 的流体状态不一, 过冷液流人补偿器后 受蒸发器漏热影响温度升高, 直至毛细芯内表面(10、 $10^{\prime} 、 10^{\prime \prime}$ ), 由于毛细芯内表面与补偿器热力状态一致, 一般认为毛细芯内表面的工质到达了饱和状态. 随后 各回路工质在流过毛细芯到达毛细芯外表面弯月面处 $\left(11 、 11^{\prime} 、 11^{\prime \prime}\right)$, 该过程由于多孔结构流阻较大, 蒸发器 加热的影响, 工质压力降低且产生一定过热度, 最后在 毛细芯外表面相变为气体，等温条件下压力产生跃迁. 循环往复进行保证了MeLHP的稳定运行.

设计的三蒸发器回路热管样机的实际结构及测点 如图3所示, 蒸发器单元壳体采用无氧铜为材料, 毛细 芯为烧结铜粉, 气液管线均采用外径 $6 \mathrm{~mm}$, 厚度 $1.5 \mathrm{~mm}$ 铜管. 冷凝器采用涡旋嵌管式设计, 将蛇形铜管 嵌人铝板内槽道中, 并联管路分流处采用三通接头连 接. 该回路热管以乙烷为换热工质，工作温区为 $170 \mathrm{~K}$, 充液率依据单蒸发器LHP的经验值设计为 0.6 (本研究 充液率是指回路热管在工作温区下液体体积占整个回 路容积的比例). MeLHP实际加工装配的基本参数如表 1所示.

根据与冷凝器相对位置关系, 由远至近将蒸发器
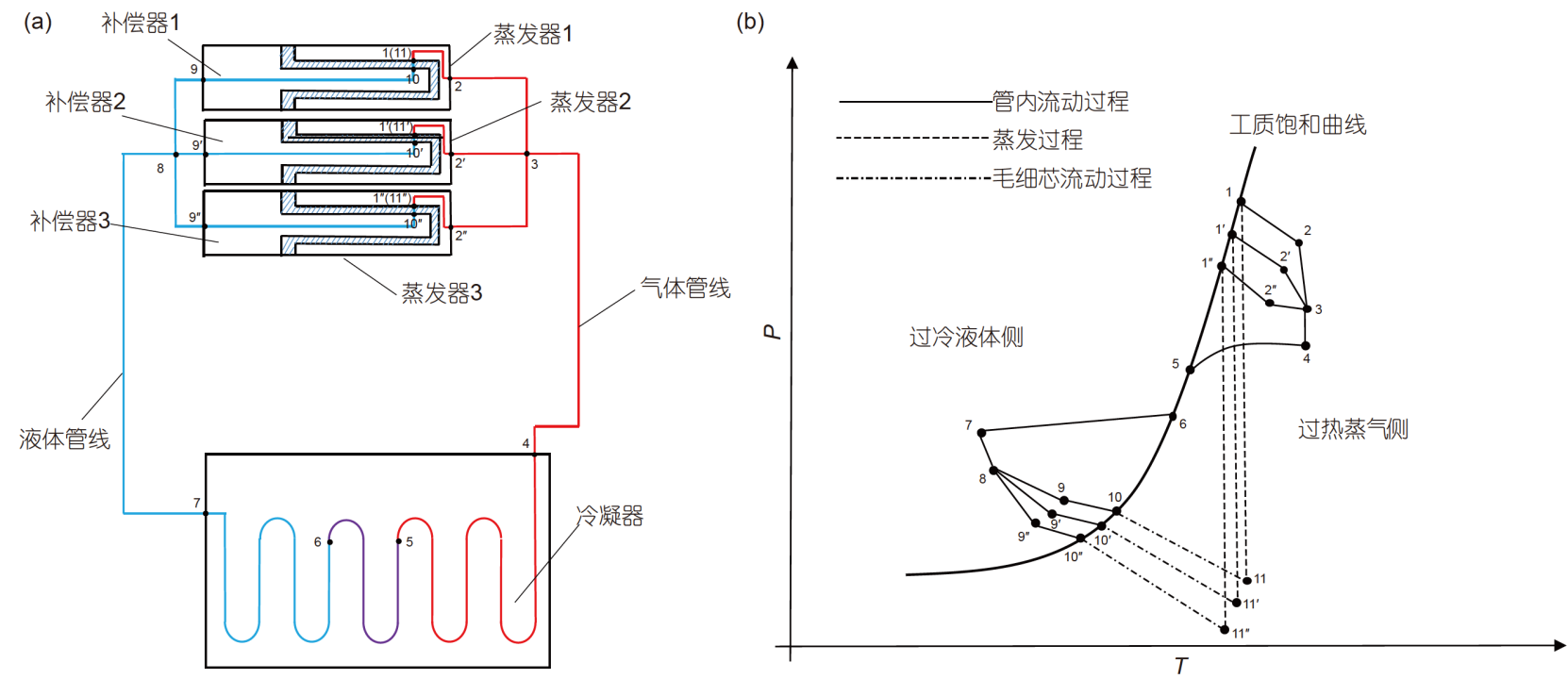

图 2 (网络版彩色)多蒸发器回路热管. (a) 结构示意图; (b) 热力过程曲线

Figure 2 (Color online) Multi-evaporator loop heat pipe. (a) Schematic diagram; (b) thermodynamic process curve 


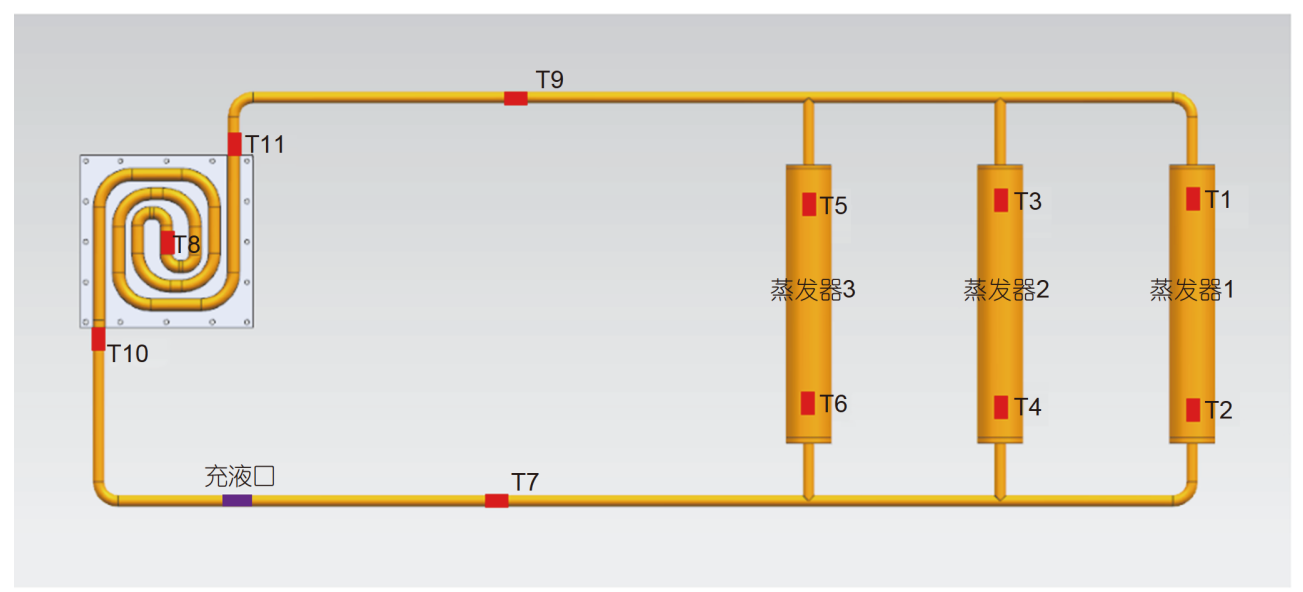

图 3 (网络版彩色)多蒸发器回路热管测温点分布

Figure 3 (Color online) Temperature measuring point settings of multi-evaporator loop heat pipe

表 1 MeLHP样机基本参数

Table 1 Basic parameters of the MeLHP prototype

\begin{tabular}{cc}
\hline 类别 & 参数 \\
\hline 蒸发器数目 & 3 \\
设计温区 & $170 \mathrm{~K}$ \\
充装工质 & 乙烷 \\
壳体、管线材料 & 紫铜 \\
吸液芯材料 & 铜粉烧结 \\
气体管线 & $810 / 720 / 630 \mathrm{~mm}$ \\
液体管线 & $695 / 605 / 515 \mathrm{~mm}$ \\
充液率 & $0.6 / 0.7$ \\
加热方式 & 薄膜加热片 \\
加热片大小及电阻 & $20 \mathrm{~mm} \times 50 \mathrm{~mm} / 20 \Omega$ \\
测温方式 & 铂电阻PT1000 \\
\hline
\end{tabular}

编号为蒸发器1(E1)、蒸发器2(E2)、蒸发器3(E3), 测 点涵盖了每个支路的补偿器、蒸发器温度，气液管线 温度, 冷凝器及其进出口温度. 获取低温的冷源采用脉 管制冷机, 冷头与MeLHP冷凝器通过安装冷板相耦合, 为保证制冷机的正常运行，同时确保低温工况下尽可 能减少环境漏热, 实验于真空罐内进行, 并在热管安装 后包覆多层绝热材料(填充涤纶丝网的双面镀铝聚酯 薄膜). MeLHP通过铂电阻PT1000进行温度测量, 加热 采用薄膜加热片, 大小 $20 \mathrm{~mm} \times 50 \mathrm{~mm}$, 阻值 $20 \Omega$, 与蒸 发器外壳紧密黏连. 罐外数据采集仪和直流电源的引 线经由罐体的接插件与罐内的温度测点和加热片 相连.

实验充分地保证每次实验的初始状态一致. 低温
工质充装采用液氮浴的方式，充装量偏差保持在 $\pm 0.5 \mathrm{~g}$ 以内，充装完毕后置于室温环境足够长时间回温后再 置于真空罐中安装. 安装状态为水平状态, 由于回路热 管管线具有柔性，安装时应充分保证蒸发器自身以及 蒸发器与冷凝器的相对水平, 蒸发器补偿器自身两端 管线坚直高度差不超过 $0.5 \mathrm{~mm}, 3$ 个蒸发器相对位置坚 直高度差最大不超过 $1 \mathrm{~mm}$, 冷凝器与蒸发器最大坚直 高度差不超过 $2 \mathrm{~mm}$. 关罐后真空度低于 $10^{-3} \mathrm{~Pa}$ 后再进 行实验, 并于实验过程中持续关注真空度, 同时室内采 用空调将环境温度控制在 $25^{\circ} \mathrm{C}$ 左右.

\section{2 启动特性实验研究}

\section{1 单蒸发器回路热管启动试验}

为了比较多蒸发器回路热管(MeLHP)与单蒸发器 回路热管(LHP)启动现象的异同，在MeLHP样机装配 前, 对所用的蒸发器装人LHP进行性能测试, 充装工质 同样为乙烷, 充液率为 0.6 . 其降温及启动过程曲线如图 4所示.

开启脉管制冷机开始降温，稳定制冷机输人功率 $150 \mathrm{~W}$ (所有工况的降温过程制冷机开始的输人功率均 为 $150 \mathrm{~W}$ ), 冷端温度曲线开始下降. 施加恒定加热功率 $5 \mathrm{~W}$ 后，热端温度经历大约 $10 \mathrm{~min}$ 的上升后开始下降， 热管成功启动. 由于该回路热管的补偿器与蒸发器采 用一体式设计，施加热负载的蒸发器对补偿器及流人 补偿器的过冷液体产生漏热, 因而加热后, 处于同一壳 体下的蒸发器与补偿器温度几乎保持一致. 同时, 气体 管线温度迅速上升, 并且在降温过程中, 气体管线温度 


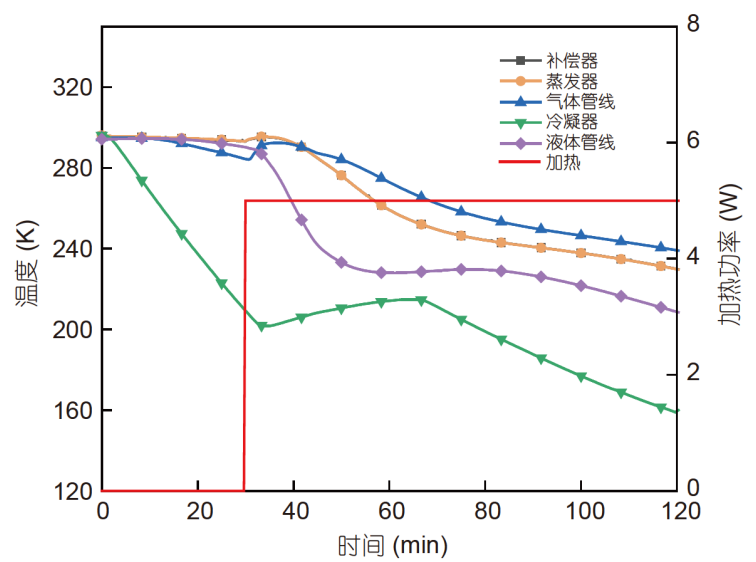

图 4 单蒸发器回路热管降温启动过程

Figure 4 Single evaporator loop heat pipe cooling and start-up process

最高, 这一方面是由于气体管线温度反映了过热蒸气 的温度, 蒸发器由于受到漏热影响温度较低; 另一方面 在低温环境下, 环境漏热对气体管线加热, 也会导致气 体管线温度的上升. 降温过程大约持续 $120 \mathrm{~min}$ 后冷端 到达 $170 \mathrm{~K}$ 温区, 从温度曲线可以看出, 在 $5 \mathrm{~W}$ 热负载
工况下，单蒸发器回路热管LHP能够在温度缓慢降低 的趋势下启动, 启动过程温度曲线变化较为平稳.

\subsection{MeLHP启动试验}

将 3 个蒸发器按设计方式与管线、冷凝器装配, 在 单蒸发器LHP的实验参照下进行MeLHP的启动特性研 究. 采用了单个蒸发器加热和多个蒸发器共同加热两 种方式进行启动实验.

图5(a)为依次对单蒸发器加热的多蒸发器回路热 管降温启动过程, 可以发现, 开启制冷机后, 回路热管 冷凝器开始降温, 冷凝器测点温度大幅下降, 热端温度 略微下降后保持平稳. 冷凝器一端降至 $260 \mathrm{~K}$ 后, 首先 对 $\mathrm{E} 1$ 施加 $5 \mathrm{~W}$ 加热功率, 热端温度短暂上涨后迅速下 降, 温度变化较单蒸发器LHP更为剧烈. 3 个蒸发器中, 首先下降的并非是受热负载的E1, E3由于更加靠近冷 凝端而其温度率先下降，降温速率明显高于E1、E2. 3 条温度曲线以很高的重合度进行降温过程. 可以发现, 即便热负载只施加于单个蒸发器, 未加热的E2和E3也 在E1热负载的作用下完成相同启动过程, 这说明了并
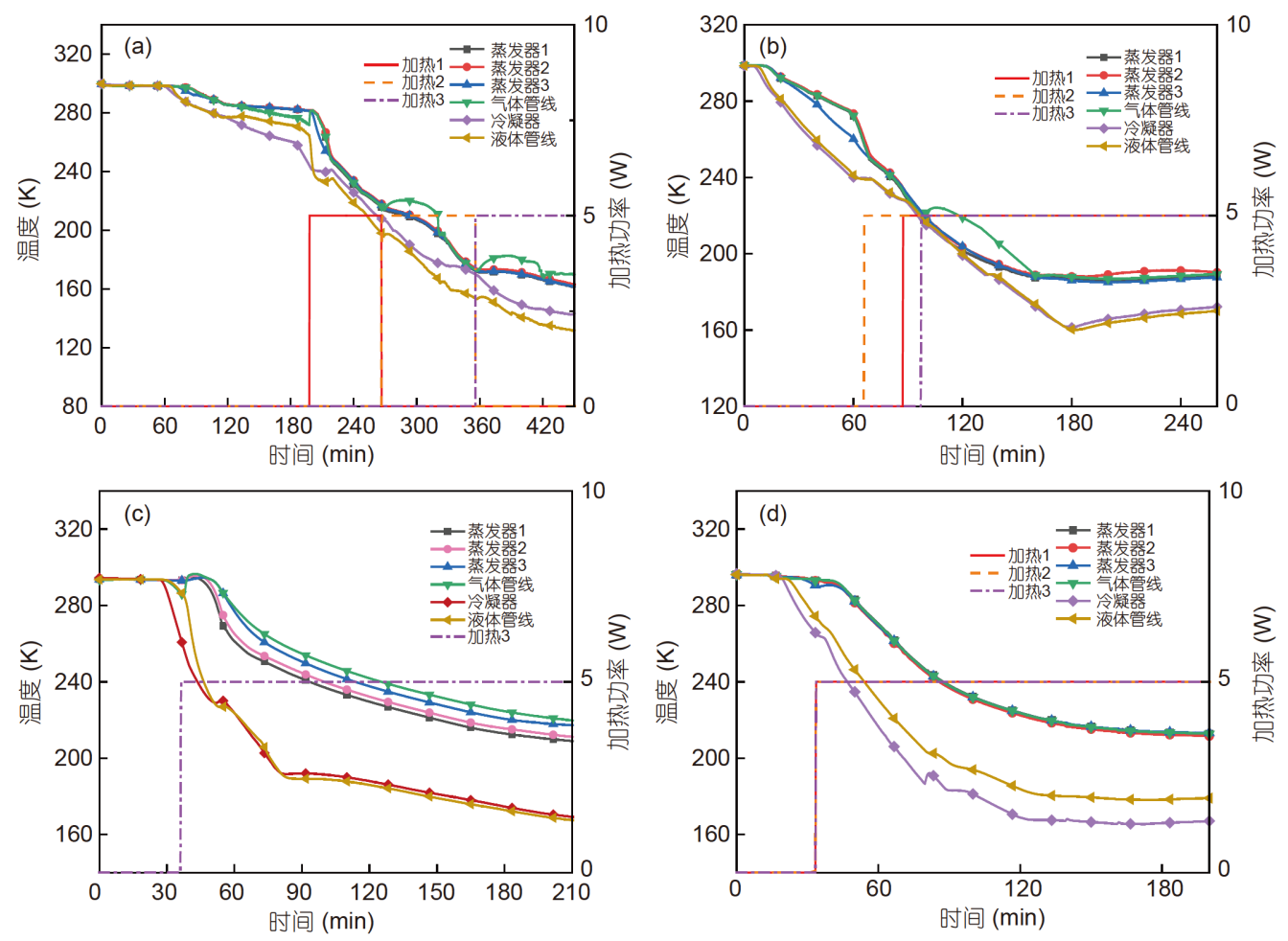

图 5 MeLHP降温启动过程. (a) 单蒸发器加热(充液率0.6); (b) 三蒸发器同时加热(充液率0.6); (c) 单蒸发器加热(充液率0.7); (d) 三蒸发器同时 加热(充液率0.7)

Figure 5 Cooling and start-up process of MeLHP. (a) Single evaporator heated (charging ratio is 0.6); (b) multiple evaporators heated (charging ratio is 0.6 ); (c) single evaporator heated (charging ratio is 0.7 ); (d) multiple evaporators heated (charging ratio is 0.7 ) 
联气耦合管路上的蒸发器的热量可以由受热蒸发器向 未受热蒸发器分享.

在冷凝器温度持续下降的过程中, 将E1单独加热 $5 \mathrm{~W}$ 的热负载, 依次切换至E2加热 $5 \mathrm{~W} 、 \mathrm{E} 3$ 加热 $5 \mathrm{~W}$ 的 工况. 可以发现, 每当切换工况时, 气体管线处测点温 度会形成一次即时的温度波动，随后会随整个回路热 管的蒸发器温度趋势继续降温. 在小功率加热下, 热管 内工质流动流量较少. 产生这些波动的原因是, 低充液 率条件下, 热端蒸发的气体在气体管线聚集成气团, 在 切换工况的过程中, 不同蒸发器受热导致了过热蒸气 流向的改变, 因此原有的热共享状态打破, 影响了回路 的正常流动. 由于回路工质流量小, 气体管线热量无法 及时排散局部温度升高, 此时局部降温存在一定滞后 性，一段时间后，气流恢复稳定，在气耦合热分享的作 用下, 气线的热量重新分配给各路蒸发器, 由于加热总 功率没有改变, 曲线保持了原有的降温趋势. 可以看到, 无论热负载施加在哪个蒸发器上, 3 条蒸发器曲线始终 保持温度一致, 因而单蒸发器加热工况下加热回路的 选择对启动特性无影响. MeLHP在单蒸发器加热情形 下能够快响应地完成降温启动过程.

图 5(b)为三蒸发器同时加热时MeLHP的启动过程 曲线. 制冷机开启约 $5 \mathrm{~min}$ 后, 在漏热影响下开始了自启 动过程, 距离冷凝器较近的 $\mathrm{E} 3$ 温度下降速率最快. 冷凝 器降至 $260 \mathrm{~K}$ 后开启加热, 依次对各个蒸发器施加 $5 \mathrm{~W}$ 的加热功率, 直至 3 个蒸发器同时加热 $5 \mathrm{~W}$. 可以看到, 选择先对E2加热各回路也同样有良好的热分享性，并 且在两路加热、三路加热的工况变换下该热分享性不 受影响, 温度曲线始终不分离. 因此, 结合单蒸发器加 热的实验曲线即可说明, 三蒸发器加热顺序变化和加 热方式变化不会影响三蒸发器间的热分享性，即不会 对三蒸发器在启动过程中产生差异性的影响.

然而, 总功率大小变化会影响整体的降温速率. 每 增加一路蒸发器加热后, 由于总功率的增加, 回路内环 流动工质的增加, 3 个蒸发器换热效率增加, 3 条温度曲 线斜率同时增大, 并且同单蒸发器加热工况一致, 出现 了气体管线温度小段的上升波动，波动后恢复至与蒸 发器同温, 热量先于气体管线中聚集后排散, 这同样是 工况变化后气体管线散热滞后性引起的. MeLHP在多 蒸发器同时加热的情形下能够成功地降温启动.

为了验证不同充液率条件下降温过程的异同，将 充液率提升至 0.7 进行了启动试验，同样进行了单蒸发 器加热和多蒸发器共同加热的启动过程. 单蒸发器加热降温启动过程如图5(c)所示, 制冷机 开启后, 对 $\mathrm{E} 3$ 单独加热, 加热后热端温度经历短暂上升 后下降, 进人启动状态, 直至稳定. 此时, 较高充液率情 形有所不同，其一表现在高充液率下，热端响应变慢， 有明显温升过程, 降温过程温度变化较为平稳, 气体管 线温度没有突然的波动, 到达指定温度后, 冷热端的稳 定温差较低充液率时更大. 其原因是在施加相同热负 载时, 高充液率的MeLHP由于回路内压力较高, 相变 过程中产生气体工质的体积小，因而气体管线呈两相 状态, 回路热管未完全启动, 这就导致气体管线出口进 人冷凝器的气体含量少或在进入冷凝器前已经全部液 化, 直接导致了冷凝器内发生极少的相变换热. 由于单 相换热效率低, 因而整个回路冷热端温差较高. 其二表 现在整个过程中，3条蒸发器曲线并没有像低充液率时 重合度很高, 而是呈现一定的温差, 受热回路的蒸发器 E3温度略高于E1、E2，并且整个降温过程各蒸发器维 持这一温差缓慢降温. 这同样是由于在小功率加热条 件下, 热管不处于完全蒸发状态, 气体管线没有形成气 团的聚集, 呈气液两相状态, 因而相互间的热分享较低 充液率条件下弱. 同时液体存在时, 管线漏热较大, 导 致了气体管线温度较蒸发器高并保持平稳.

多蒸发器同时加热降温启动过程如图 5(d)所示, 对 三蒸发器同时加热 $5 \mathrm{~W}$ ，加热开启后一段时间，热端温 度开始缓慢下降. 同时加热条件下, 降温曲线依然符合 由于充液率增大降温变缓的现象. 由于总功率的增加, 回路热管蒸发量增加, 气体管线为连续的气相, 此时漏 热影响较小，因而气体管线在热分享性下保持与蒸发 器同温, 温度曲线几乎重合.

\section{3 实验结果分析}

从图5的曲线可以看出, 不同充液率不同加热方式 下，降温启动过程中各蒸发器之间均表现出了良好的 热分享特性. 加热功率相同的条件下, 低充液率和高充 液率下三蒸发器的温度曲线均为几乎重合; 单蒸发器 加热条件下, 低充液率仍保证了较高一致性, 而高充液 率下各蒸发器曲线出现分离, 降温启动过程中蒸发器 间保持稳定的温差, 受热负载的回路温度略高.

MeLHP的实验结果对比单蒸发器回路热管的启动 过程, 0.7 充液率条件下的启动过程更符合单蒸发器的 对照实验. 其原因在于，正常符合设计条件的回路热 管, 在小功率加热启动过程中, 热量往往不能满足完全 蒸发条件, 工质未达到完全流动的状态, 参与循环的流 
量很小, 蒸发器通常表现为不连续的小气泡接连逸出, 气体管线未达到完全过热气体充盈的状态. 同时加热 时, 每个蒸发器受相同热负载影响, 产生气泡的大小、 流速维持在相当水平, 因而温度差别很小. 而在单一加 热情形下, 受热蒸发器正常启动. 未受热的蒸发器在受 热蒸发器热分享下启动, 在此种情况下热量分享的比 例是有限的, 不可能保持与受热回路完全一致的热力 状态, 温度理应偏低. 而充液率不足的情况下, 小功率 加热的条件便使得各个蒸发器出口及相连管线充满过 热蒸气，气体的扩散性和高速流动使回路热管在气耦 合作用下各蒸发器的热力状态保持高度一致. 此时由 于循环的工质流量小, 充液率不足的情况下, 回路无法 完全依靠冷凝液回流补液, 因而此时蒸发器受补偿器 漏热影响较小, 这也正是低充液率时气体管线温度没 有高于蒸发器温度的原因.

对比还发现, 对于各个工况的降温过程, 均不同程 度地出现了 $\mathrm{E} 3$ 温度低于 $\mathrm{E} 1 、 \mathrm{E} 2$ 的小段波动. 其中, 两种 充液率下单蒸发器加热时E3曲线分离出现在开启加热 后, 而三蒸发器同时加热的工况曲线分离在开启加热 前. 这是MeLHP不同的初始工质分布状态造成的. 工 质充装后, 实验设定先进行单蒸发器加热启动实验, 后 进行共同加热实验. 单蒸发器加热启动实验降温时, 热 管由于没有运行过，各补偿器基本维持工质的均匀分 布，因而加热前的自启动阶段 3 支路流量基本一致，维 持相同温度. 热负载施加后, 回路内流量增加, 非对称 结构影响下, E3 回路流量分配较多导致其换热效率的 突增, 随后在气耦合热分享的协调作用下, 三回路温度 趋于统一. 而后进行的多蒸发器共同加热实验是热管 运行过后的二次实验, 由于热管运行过程中出现流量 分配不均的特性, 管线较短的E3会分配较多流量, 自然 回温状态下保持这一分配状态. 因而二次实验时, 在漏 热驱动的自启动阶段便出现了 $\mathrm{E} 3$ 温度曲线的分离, 该 分离在回路热管加热后同样由于热分享特性维持了随 后各蒸发器温度的一致. 因此, 工质在各回路的初始分 配状态会对启动过程产生影响, 但由于气耦合条件下 热分享的存在, 由此产生的蒸发器降温速率不一的影 响会被消除.

此外, 为了更加直观地描述不同启动过程的差异, 将整合实验数据进行对比. 针对各个启动过程中的热 端响应特征, 以回路热管加热后 $2 \mathrm{~h}$ 内蒸发器 $\mathrm{E} 1$ 的温度 变化为参考, 各工况下的对比如图6所示.

从该曲线可明显看出, 无论何种工况, 在冷端与热

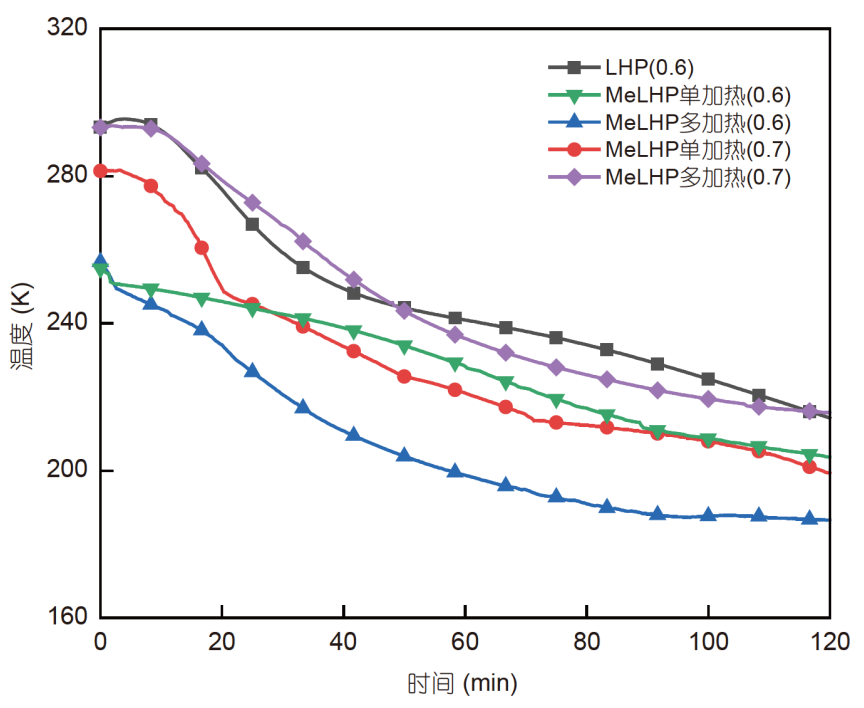

图 6 各实验过程蒸发器温度变化对比

Figure 6 Comparison of evaporator temperature changes in different experiments

端有一定温差的前提下, 加热都会加速回路热管内工质 的流动, 加速蒸发器与冷端的热交换而促进回路热管的 启动过程. 同时，由于各蒸发器之间有良好的热交换特 性，MeLHP中每一路的蒸发器都能在热分享下完成启 动过程，很好地继承了单蒸发器回路热管的启动特性, 并且适用于LHP的“降温产生冷热端温差——施加热负 载推动工质流动”的启动方式仍然适用于MeLHP.

与 0.6 充液率条件相比较, 0.7 充液率下的MeLHP和 0.6 充液率的LHP在加热后蒸发器均在小段温升后降 温, 启动过程曲线的一致性相对较高. 实验过程中, 启 动过程对应相同的操作, 即开制冷机降到 $240 \mathrm{~K}$ 附近后 开启加热. 图6中可以看到，开始加热时，0.7充液率的 MeLHP和0.6充液率的LHP温度较高, 而0.6充液率的 MeLHP充液率相对较低, 这是因为开启制冷后, MeLHP冷端温度骤降, 回路热管内部工质温度不一致 导致密度不一致, 工质会自发地向冷端流动和聚集, 导 致热端含气量增加, 在一定环境漏热的影响下, 低温回 路热管易出现自启动现象, 即未加热源热管内便产生 工质的流动. 而低充液率条件对自启动现象更加敏感, 更易发生, 因而其热端温度较低. 我们发现对于常用的 0.6 充液率的LHP仍需要小功率加热, 热端才有较大变 化, 从图6中可以看出MeLHP在 0.7 充液率条件下才能 保证与其启动曲线的相似.

对各个过程进行降温速率的比较, 实验开始降温, 各工况保持了相同的 $150 \mathrm{~W}$ 制冷机输人功率, 而当冷端 
温度降低至 $200 \mathrm{~K}$ 以后, 为保证该MeLHP热管最终稳定 在设定温区 $170 \mathrm{~K}$ ，对制冷机功率进行了机动的调整. 因此, 本实验中考察降温速率为加热开启后蒸发器温 度到达 $200 \mathrm{~K}$ 时间内的温度变化率, 对MeLHP取多个蒸 发器温度的算术平均. 上述各个过程的启动过程时间 和降温速率对比如图7所示.

由降温速率的对比可以直观看出MeLHP在 0.6 充 液率情形下, 两种加热方式热端降温速率明显高于充 液率 0.7 的MeLHP以及单蒸发器LHP. 验证了低充液率 条件下降温速度快，以及充液率 0.7 启动特性更符合单 蒸发器回路热管的结论. 更进一步说明了对于MeLHP 充液率的选取需要高于对应单蒸发器回路热管的充液 率才能满足一致的启动性能.

\section{3 结论}

本研究通过对比单蒸发器回路热管、对比不同加 热方式以及对比不同充液率的方式，详细描述并分析 了多蒸发器回路热管(MeLHP)的降温过程与启动特性, 得出结论如下.

(1) 多蒸发器回路热管(MeLHP)中各个蒸发器继承 了单蒸发器回路热管的启动特性. 热管冷端降温使冷 热端产生一定温差, 在漏热作用下进人自启动状态. 对 蒸发器施加小功率热负载后, 加速MeLHP冷热端曲线 的闭合, 冷端温度稳定后热端也迅速稳定.

(2) 从多蒸发器回路热管(MeLHP)的整个降温、启 动过程可以看出, 无论是单一蒸发器加热还是多个蒸 发器共同加热的方式, MeLHP样机均能顺利启动. 由 于气耦合结构的分享作用, 各个启动降温过程中各蒸

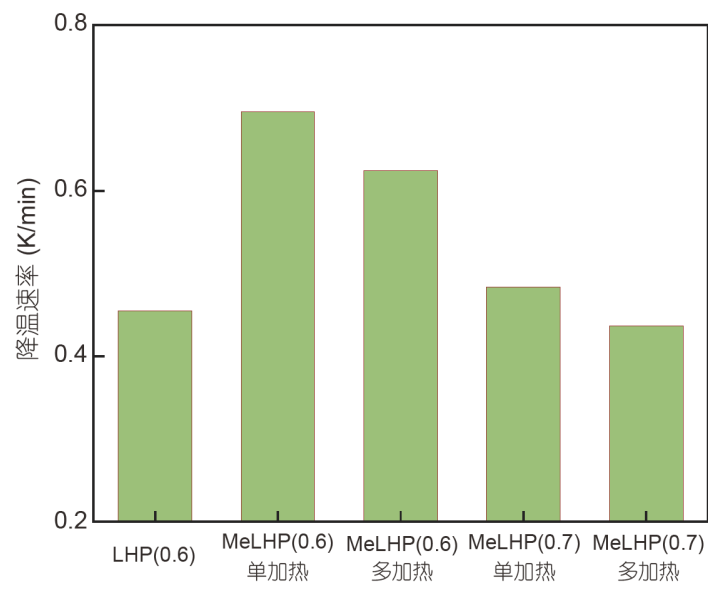

图 7 (网络版彩色)各实验过程降温速率对比

Figure 7 (Color online) Comparison of cooling rate in different experiments

发器温度基本维持一致, 即使只有单回路加热, MeLHP中的加热回路也能带动未加热蒸发器正常启 动, 且热分享特性不受加热分配方式的影响. 各蒸发器 温度曲线在开始降温时会受到工质在补偿器内初始分 配的影响，蒸发器间的热交换作用可消除其影响而保 证温度的一致性.

(3) 在小功率加热启动的条件下, 虽然充液率 0.6 的 MeLHP有着更快的热响应和更优良的热分享特性，充 液率0.7条件下的MeLHP启动特性更加接近LHP充液 率0.6的启动特性，因而为了使MeLHP各回路的性能与 参照单回路热管性能匹配, MeLHP充液率在0.7时启动 性能最优. 所以对于多蒸发器回路热管, 其指导充液率 应一定程度上高于单蒸发器回路热管对应值.

\section{参考文献}

1 Zhao Y, Yan T, Liang J. Experimental study on a cryogenic loop heat pipe with high heat capacity. Int J Heat Mass Transf, 2011, 54: 3304-3308

2 Liu W, Liu Z C, Yang K, et al. Phase change driving mechanism and modeling for heat pipe with porous wick (in Chinese). Chin Sci Bull, 2009, 54: 1932-1936 [刘伟, 刘志春, 杨昆, 等. 毛细芯热管的相变驱动机制与模型. 科学通报, 2009, 54: 1932-1936]

3 Hong S H, Tang Y L, Zhang X Q, et al. Multiple orientations research on heat transfer capabilities of ultra-thin loop heat pipes with various channel configurations (in Chinese). Chin Sci Bull, 2017, 62: 721-729 [洪思慧, 唐永乐, 张新强, 等. 不同蒸发器结构的超薄平板环路热管的传热性能 的差异化. 科学通报, 2017, 62: 721-729]

4 Qu Y, Wang S, Tian Y. A review of thermal performance in multiple evaporators loop heat pipe. Appl Thermal Eng, 2018, 143: 209-224

5 Maydanik Y F, Pastukhov V G, Chernyshova M A, et al. Development and test results of a multi-evaporator-condenser loop heat pipe. In: AIP Conference Proceedings, 2003, 654: 42-48

6 Bienert W B, Wolf D A, Nikitkin M N, et al. Proof-of-feasibility of multiple evaporator loop heat pipes. In: Proceedings of the Sixth European Symposium on Space Environmental Control Systems, 1997

7 Yun S J, Wolf D A, Kroliczek E. Design and test results of multi-evaporator loop heat pipes. SAE Trans, 1999, 108: 525-531

$8 \mathrm{Ku}$ J, Ottenstein L, Douglas D, et al. Miniature loop heat pipe with multiple evaporators for thermal control of small spacecraft. In: Government Microcircuit Applications and Critical Technology Conference, 2005 
9 Nagano H, Ku J. Capillary limit of a miniature loop heat pipe with multiple evaporators and multiple condensers. In: 9th AIAA/ASME Joint Thermophysics and Heat Transfer Conference. Reston: American Institute of Aeronautics and Astronautics, 2006. AIAA 2006-3110

10 Yun J, Wolf D, Hoang T, et al. Multiple evaporator loop heat pipe. In: 30th International Conference on Environmental Systems. SAE Technical Paper, 2000

11 Bugby D C, Kroliczek E J, Yun S J, et al. Development and testing of a miniaturized multi-evaporator hybrid loop heat pipe. In: AIP Conference Proceedings, 2005

12 Yun J, Bugby D. Thermal performance of multi-evaporator hybrid loop heat pipe (ME-HLHP) with a liquid cooled shield (LCS). In: 5th International Energy Conversion Engineering Conference and Exhibit (IECEC), 2007

13 Chen J, Zhang H, Ju Y L. Recent development of multi-evaporator CPL heat pipe and nano-fuild applied to heat pipe (in Chinese). Cryogenic Supercond, 2011, 39: 42-48 [陈健, 张华, 巨永林. 多蒸发器CPL热管及纳米流体应用于热管的研究进展. 低温与超导, 2011, 39: 42-48]

14 Liu C Z, Yang F, Dong D P, et al. Experimental investigation on ethane double-evaporator cryogenic loop heat pipe (in Chinese). Low Temp Spec Gases, 2012, 30: 7-11 [刘成志, 杨帆, 董德平, 等. 乙烷双蒸发器低温回路热管的实验研究. 低温与特气, 2012, 30: 7-11]

15 Guo Y, Lin G, He J, et al. Experimental study on the supercritical startup and heat transport capability of a neon-charged cryogenic loop heat pipe. Energy Conv Manag, 2017, 134: 178-187 


\title{
Startup characteristics of a multi-evaporator cryogenic loop heat pipe
}

\author{
Depu Lu ${ }^{1,2}$, Rongjian Xie ${ }^{2 *}$, Jiajia Wen ${ }^{2}$ \& Cheng Liu ${ }^{2,3}$ \\ ${ }^{1}$ University of Chinese Academy of Sciences, Beijing 100049, China; \\ ${ }^{2}$ Shanghai Institute of Technical Physics, Chinese Academy of Sciences, Shanghai 200083, China; \\ ${ }^{3}$ School of Information Science and Technology, ShanghaiTech University, Shanghai 201210, China \\ * Corresponding author, E-mail: xierongjian@mail.sitp.ac.cn
}

With the rapid development of space exploration technology, the traditional point-to-point heat transfer methods cannot fulfill the heat dissipation requirements of multi- and large-array detectors. Loop heat pipe is an effective and efficient twophase heat transfer device that has played a significant role in spacecraft for the thermal control system. In addition, it has high heat transfer efficiency, long heat transfer distance, heat switch characteristics, and pipeline flexibility. However, higher requirements are proposed for space thermal control. We need to design and handle more complicated detector structures, heat dissipation from scattered distribution, and heat dissipation of large area array.

In this work, a heterotypic loop heat pipe has been investigated to solve the heat dissipation issue of a multi-point distributed heat source. A multi-evaporator loop heat pipe (MeLHP) in low temperature is designed and manufactured, via connecting three evaporators in parallel with gas coupling method. The pipelines are arranged asymmetrically as required. The working temperature is set to $170 \mathrm{~K}$ while ethane has been used as a working fluid. A series of experiments are conducted to study the start-up characteristics of the prototype. Different heating methods and various charging ratios are compared with a single evaporator loop heat pipe, where the MeLHP prototype is explored variously in the process of cooling and start-up.

Initially, a start-up experiment of a single evaporator loop heat pipe is carried out. As we know, the loop heat pipe (LHP) research is relatively mature, so all the conditions of LHP are adopted for the startup characteristics of MeLHP's. It is found that every single evaporator of MeLHP has similar performance to that of LHP. Later, we employ different experimental conditions on the evaporators such as various charging ratios and different heating methods. The temperature fluctuation and heat sharing characteristics are compressively analyzed from the comparison of temperature curves at different working conditions. Finally, the experimental process is verified from the nice comparison of single evaporator temperature change and cooling rate of each case.

In addition, we observe that evaporators in each loop of MeLHP are highly uniform compared to that of a single evaporator loop heat pipe, during the start-up process. So, MeLHP can start under the condition of single evaporator heating and multiple evaporators heating as well. When a single evaporator heating process takes place in MeLHP, the unheated evaporators share the heat via the influence of gas coupling from the heated evaporators. So, this process simultaneously starts three evaporators; the initial state of working fluid would influence the temperature of each evaporator during cooling, while the heat exchange of gas coupling effectively inhibits the effect of evaporators' temperature. The structure of gas coupling effectively shares the heating load among all evaporators. Different charging ratios affect the start-up process of MeLHP. Compared to the charging ratio of LHP (0.6), the results of MeLHP are consistent with LHP at a charging ratio of 0.7 . So, the fluid charging ratio of MeLHP should be appropriately increased to obtain an equivalent performance to that of a single loop heat pipe.

Our experiments have verified the start-up feasibility of a multi-evaporator loop heat pipe with parallel gas coupling, revealed the law of cooling, and the start-up process, which is highly significant for the promotion and application of MeLHP.

multi-point distributed heat source, multi-evaporator loop heat pipe, cooling process, start-up characteristic, charging ratio

doi: 10.1360/TB-2019-0568 